\title{
Model Pengembangan Aktivitas Wisata di Kawasan Sungai Cilimbung Kabupaten Garut
}

\author{
"Tourism Activity Development Model in the Cilimbung River Area, \\ Garut Regency"
}

Oleh:

\author{
Mega Fitriani Adiwarna Prawira1; Beta Budisetyorini' ${ }^{2}$; \\ Deddy Adisudharma; ; Dicky Arsyul Salam ${ }^{4}$ \\ 1,2,3,4 Sekolah Tinggi Pariwisata Bandung \\ megafitriani@stp-bandung.ac.id; beta@stp-bandung.ac.id; \\ latitudesbdg@gmail.com; Dicky@stp-bandung.ac.id
}

\begin{abstract}
ABSTRAK
Pariwisata menjadi salah satu sektor bisnis unggulan yang terus mengalami perkembangan dalam kajian akademis. Penelitian ini bertujuan mengungkap model pengembangan aktivitas wisata dalam mendukung peningkatan bisnis masyarakat di Kawasan Sungai Cilimbung Kabupaten Garut. Metode yang diterapkan yaitu deskriptif-kualitatif dengan unit analisis sumberdaya produk dan sumberdaya sosial di lokasi penelitian. Penelitian ini telah menemukenali konsep aktivitas wisata yang sesuai untuk dikembangkan di Kawasan Sungai Cilimbung berdasarkan konsep experiential tourism. Selanjutnya, penelitian ini telah menghasilkan pemetaan minat dan kepentingan stakeholder terkait, untuk dikaji lebih jauh dalam pengambilan keputusan pembangunan bagi pemerintah dan masyarakat.
\end{abstract}

Kata kunci: destinasi wisata; experiential tourism; wisata sungai; community-based tourism

\begin{abstract}
Tourism is one of the leading business sectors that continues to grow in academic studies. This study aims to reveal a model for developing tourism activities in supporting community business improvement in the Cilimbung River Basin, Garut Regency. The method used is descriptive-qualitative with unit analysis of product resources and social resources at the research site. This research has identified the concept of tourism activities that are suitable to be developed in the Cilimbung River Area based on the concept of experiential tourism. Furthermore, this research has resulted in mapping the interests and interests of relevant stakeholders, to be studied further in making development decisions for the government and the community.
\end{abstract}

Keywords: tourist destinations; experiential tourism; river tours; community-based tourism 


\section{PENDAHULUAN}

Pandemi covid-19 yang terjadi sejak tahun 2019 telah memberikan dampak negatif terhadap pertumbuhan pariwisata global (Ioannides \& Gyimóthy, 2020), ditandai dengan penurunan kedatangan wisatawan internasional $65 \%$ atau setara 440 juta kunjungan pada semester I tahun 2020 (UNWTO, 2020). Kawasan AsiaPasifik tercatat menderita pertumbuhan negatif terbesar atas kunjungan wisatawan internasional sebesar $-96 \%$ diatas rata-rata global yaitu -87\% (UNWTO, 2021). Pembatasan perjalanan internasional, regional dan lokal telah mempengaruhi sistem pariwisata, yaitu perjalanan internasional, pariwisata domestik, day visit dan industri transportasi udara, kapal pesiar, angkutan umum, akomodasi, restoran, konvensi, festival, atau event olahraga (Gössling, Scott, \& Hall, 2021).

$\mathrm{Di}$ sisi lain, pandemi membawa dampak positif terhadap penurunan over tourism dan memberikan kesempatan bagi wilayah sub-urban untuk mengembangkan konsep wisata berkelanjutan berbasis lingkungan (Koh,
2020) dan smart tourism (Susanto et al., 2020). Indikator ini menunjukkan dampak pandemi terhadap perubahan preferensi, persepsi dan perilaku pasar atas perjalanan wisata (Peters et al., 2020). Menyikapi perubahan ini, pemangku kebijakan pariwisata perlu menindaklanjuti dengan pengembangan produk yang sesuai dengan perubahan tersebut (Brouder et al., 2020).

Pemerintah Jawa Barat dalam Rencana Induk Pembangunan Kepariwisataan Tahun 2015-2025 telah menetapkan 5 Destinasi Pariwisata Provinsi (DPP) yang terdiri atas Kawasan Strategis Pariwisata Provinsi (KSPP) dan Kawasan Pariwisata Provinsi (Pemerintah Provinsi Jawa Barat, 2015). Kabupaten Garut merupakan salah satu KSPP bertema pariwisata alam yang relevan dengan isu perubahan perilaku wisatawan di masa pandemi. Pengembangan pariwisata di kawasan ini memiliki tema pariwisata alam pegunungan beserta fitur yang melekat didalamnya termasuk sungai, lembah, bukit, dan pedesaan disertai upaya konservasi lingkungan.

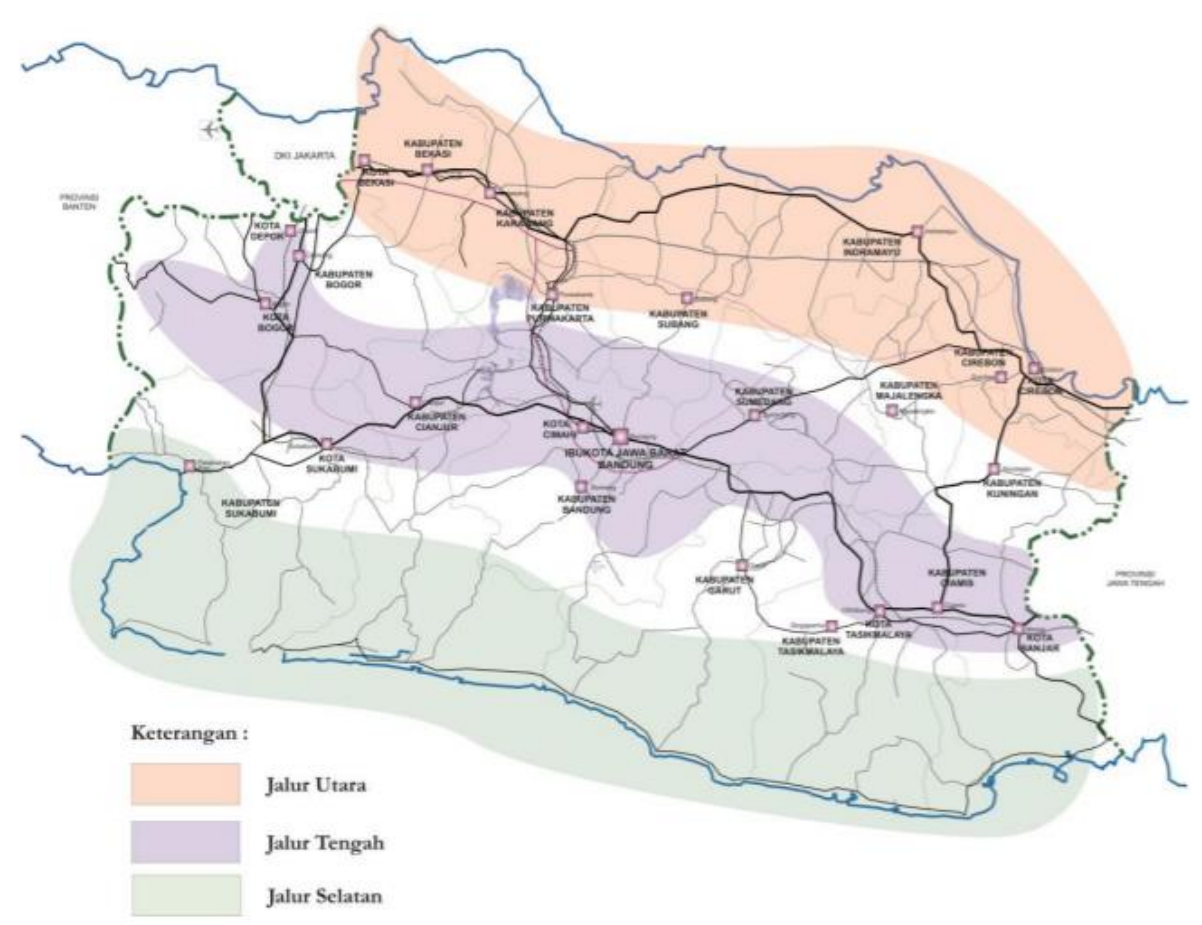

Gambar 1. Peta Kawasan Wisata Unggulan (KWU) Jawa Barat

Sumber: (BAPPEDA Jawa Barat, 2015)

2 "Mega Fitriani Adiwarna Prawira, Beta Budisetyorini, Deddy Adisudharma, Dicky Arsyul Salam:" 
Pada dokumen kebijakan lain (Badan Perencanaan Pembangunan Daerah Jawa Barat, 2017), Kabupaten Garut Selatan ditetapkan sebagai Kawasan Wisata Unggulan Minat Khusus Jawa Barat Selatan bersama Geopark CiletuhPalabuhanratu (Gambar 1.). Hal ini berkaitan dengan sumnberdaya kawasan yang sesuai untuk aktivitas petualangan berbasis gunung, rimba, sungai dan laut. Penetapan kawasan ini memberikan dampak terhadap strategi pengembangan aktivitas pada skala tapak yang tidak menghendaki pembangunan fisik secara massive, namun tetap memenuhi kaidah standar pelayanan pariwisata. Pengembangan dimaksudkan untuk menunjang quality-tourism experiences (Beardsley et al., 2018) dan experiential tourism (Kozak \& Kozak, 2018).

Desa Neglasari Kecamatan Cisompet Kabupaten Garut merupakan salah satu kawasan di Garut Selatan yang ditetapkan sebagai kawasan pengembangan pariwisata. Desa ini berada di pegunungan dengan landscape berupa gunung, bukit, lembah dengan beberapa aliran sungai dan air terjun sebagai daya tarik utama. Tutupan lahan berupa hutan dan perkebunan melengkapi daya tarik kawasan ini, memperkuat tema pengembangan pariwisata minat khusus berbasis sungai. Salah satu atraksi wisata existing yaitu Curug Jagapati, sebuah air terjun yang merupakan bagian dari Cilimbung.

Secara faktual, kawasan ini telah dikunjungi wisatawan asal Jawa Barat, khususnya pasca kunjungan gubernur Jawa Barat ke air terjun Jagapati dan mempublikasikannya secara luas di media sosial. Namun demikian, data survey penelitian pada bulan April 2021 menunjukkan pengembangan aktivitas wisata di kawasan ini belum dilakukan secara optimal. Potensi kawasan yang variatif belum mampu digunakan untuk memberikan pengalaman kunjungan bagi wisatawan. Hal ini berkaitan dengan belum adanya arahan pengembangan aktivitas wisata berbasis sungai dan tata kelola pariwisata yang masih bertumpu pada inisiatif pemerintah.

Beberapa penelitian menunjukkan bahwa pengembangan wisata sungai dapat memberikan dampak positif terhadap perekonomian wilayah (Ajake \& Amalu, 2012; Budisetyorini et al., 2021; Putro et al., 2021), pelestarian lingkungan (Mafruhah et al., 2020), dan perubahan sosial (Sheldon \& Fesenmaier, 2017). Alternatif pengembangan wisata sungai Cilimbung menggunakan kombinasi pendekatan community-based tourism (Khalid et al., 2019) dan experiential tourism (Meacci \& Liberatore, 2018; Smith, 2006) sehingga diperoleh rumusan strategi pengembangan aktivitas wisata sungai berbasis pengalaman yang mendayagunakan potensi masyarakat sebagai pelaku utama pariwisata.

Penelitian pengembangan wisata di kawasan sungai melalui prinsip experiential learning dan communitybased tourism masih memiliki peluang untuk diperluas. Hal ini diketahui bahwa konsep pengembangan kawasan pariwisata selama ini berfokus pada pengembangan fisik kawasan, atau setidaknya berangkat dari pemikiran bahwa mass-tourist merupakan pilihan yang paling baik bagi kawasan pariwisata. Penelitian ini berusaha memberikan perspektif berbeda mengenai bagaimana sebuah kawasan sungai dikemas menjadi sebuah produk yang memberikan pengalaman serta mengungkap minat dan kepentingan para stakeholder di dalamnya.

Mempertimbangkan kondisi tersebut, dilakukan penelitian terapan untuk menggali data dan informasi mengenai sumberdaya produk wisata sungai serta sumberdaya sosial di Desa Neglasari Kecamatan Cisompet Kabupaten Garut. Penelitian bertujuan merumuskan model pengembangan aktivitas wisata berbasis sungai di Sungai Cilimbung, Desa Neglasari Kecamatan Cisompet Kabupaten Garut. 


\section{METODE PENELITIAN}

Penelitian menggunakan metode deskriptif melalui pendekatan kualitatif (Veal, 2018) yang berusaha menggambarkan sumberdaya dan model pengembangan. Lokasi penelitian yaitu Kawasan Sungai Cilimbung Desa Neglasari Kecamatan Cisompet Kabupaten Garut. Penelitian dilakukan pada Bulan Mei - Juni 2021, dengan menggunakan metode pengumpulan data melalui observasi, wawancara dan studi kepustakaan untuk menghasilkan data penelitian yang dibutuhkan. Informan yang digunakan yaitu staf Dinas Pariwisata dan Kebudayaan Provinsi Jawa Barat, staf Dinas Pariwisata dan Kebudayaan Kabupaten Garut, staf Pemerintah Desa Neglasari, anggota Pokdarwis Curug Jagapati, pelaku usaha kepariwisataan dan masyarakat Desa Neglasari.

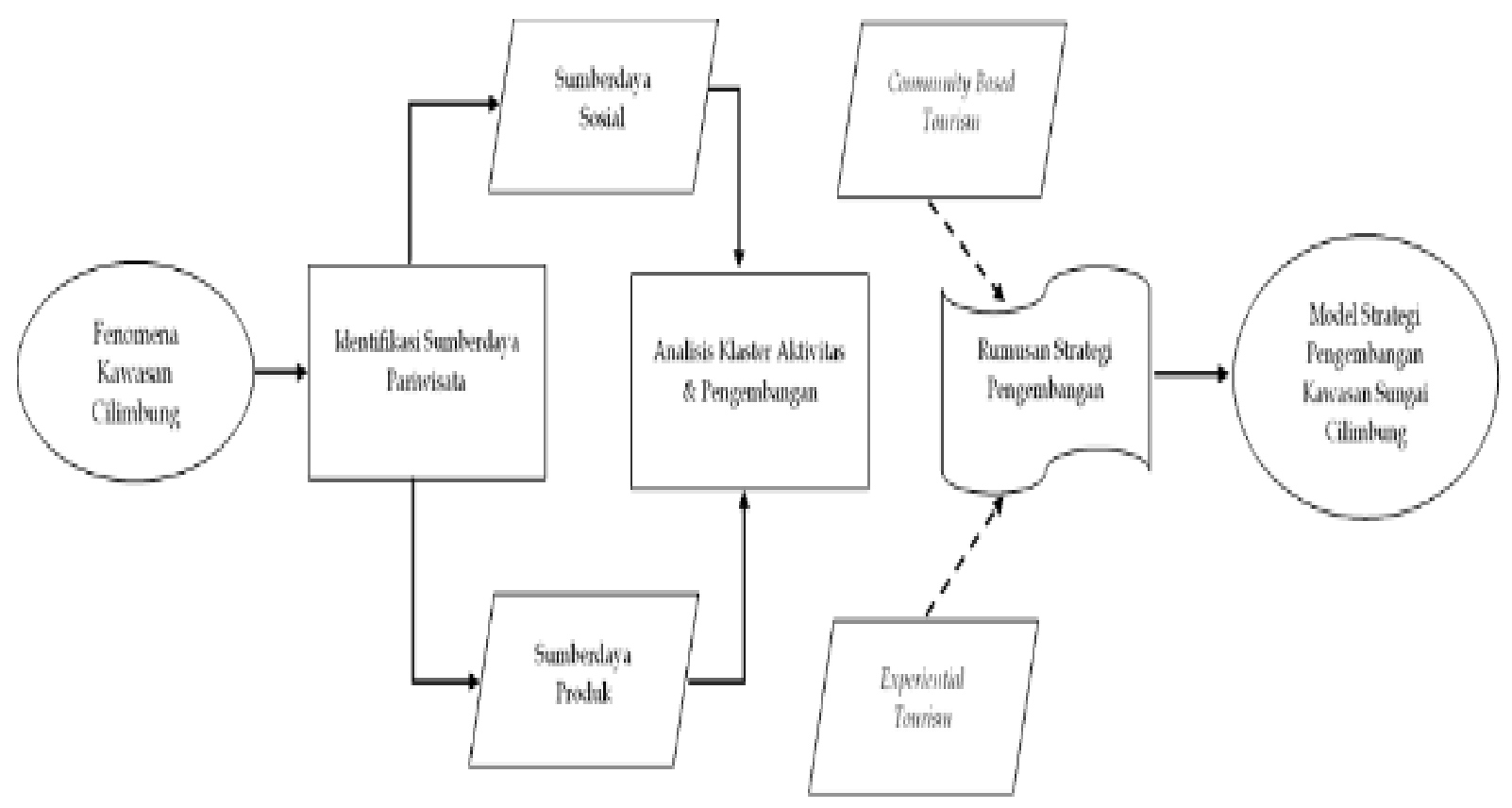

Gambar 2. Kerangka Kerja Penelitian

Sumber: modifikasi (Cooper, 2016; Khalid et al., 2019; Meacci \& Liberatore, 2018; Prawira et al., 2020)

\section{HASIL PENELITIAN DAN PEMBAHASAN}

\section{Kondisi Umum}

Kabupaten Garut berkarakter topografi variatif; wilayah utara, timur dan barat diwarnai daerah dataran tinggi berupa perbukitan dan pegunungan, pada daerah selatan sebagian besar dengan kemiringan yang cukup curam dan pantai. Pada aspek geologis termasuk dalam Zona Pegunungan Selatan Jawa Barat dan Zona Bandung (empat bentang alam satuan morfologi yaitu perbukitan berelief kasar, kerucut gunung api, pedataran dan perbukitan berelief halus). Komposisi bebatuan tersusun atas batuan terobosan, batuan sediman dan batuan vulkanik dengan struktur geologi berupa kekar, sesar dan lipatan. Jenis tanah pada umumnya terdiri atas jenis tanah aluvial serta asosiasi litosol, mediteran, podsolik, andosol, dan regosol. Jenis tanah podsolik merah ke arah kekuning-kuningan dan kuning serta regosol merupakan yang terluas di wilayah Kabupaten Garut bagian selatan, sementara bagian utara didominasi jenis tanah andosol (Peraturan Daerah Kabupaten Garut Nomor 1 Tahun 2019, 2019). Pada aspek hidrologi, wilayah Kabupaten Garut dialiri 33 sungai dengan panjang kumulatif $1.397,34 \mathrm{~km}$ termasuk 101 anak sungainya. Terdiri atas 2 Daerah Aliran Sungai utama yaitu 1) Daerah 
Aliran Selatan yang bermuara di Samudera Indonesia, berkarakter relatif pendek, sempit dan berlembah, yaitu DAS Cilaki dan DAS Cikaengan; 2) Daerah Aliran Sungai Utara dengan karakter yang relatif lebih panjang, berukuran lebar dan lebih landau, yaitu DAS Cimanuk.

Pengembangan kepariwisataan Kabupaten Garut dikembangkan melalui 1) prinsip pembangunan kepariwisataan yang berkelanjutan; 2) berorientasi pada upaya pertumbuhan, peningkatan kesempatan kerja, pengurangan kemiskinan, pelestarian adat dan kebudayaan, serta pelestarian fungsi lingkungan hidup; 3) dilaksanakan dengan tata kelola yang baik; 4) dilaksanakan secara terpadu-lintas sektor, lintas daerah dan lintas pelaku; serta 5) dilaksanakan dengan mendorong kemitraan sektor privat dan publik (Peraturan Daerah No 2 Tahun 2019 Tentang Rencana Induk Pembangunan Kepariwisataan Daerah Tahun 2019-2025, 2019). Berdasarkan hal tersebut, wilayah Kabupaten Garut dibagi 4 (empat) Kawasan Strategis Pariwisata Kabupaten (KSPK) dan 7 (tujuh) Kawasan Pengembangan Pariwisata Kabupaten KPPK(Peraturan Daerah No 2 Tahun 2019 Tentang Rencana Induk Pembangunan Kepariwisataan Daerah Tahun 2019-2025, 2019) Kawasan Sungai Cilimbung Kecamatan Cisompet termasuk pada KSPK Garut Selatan dengan tema pengembangan ekowisata bersama kawasan wisata pantai Selatan.

Wilayah penelitian yang berada di Kawasan Sungai Cilimbung Desa Neglasari Kecamatan Cisompet terletak 61 $\mathrm{km}$ dari pusat wilayah administratif Kabupaten Garut, Provinsi Jawa Barat. Terdiri atas dataran tinggi dan lembah, dengan kemiringan lahan mayoritas 15$40 \%$.

Suhu udara di wilayah penelitian berkisar 25-270 Celcius, dengan curah hujan harian antara 13,6 mm - 27,7 mm pada periode bulan basah selama 9 bulan per tahun. Pada wilayah dataran tingginya, curah hujan tahunan dapat mencapai 3.500
-4000 mm dengan angka evaportranspirasi sebesar $1.572 \mathrm{~mm} /$ tahun.

Pola pengaliran di Kawasan Sungai Cilimbung Kecamatan Cisompet terbagi menjadi dua, yaitu pola Radial dan Subdendritik. Bentuk lahan terbagi menjadi empat satuan yaitu Perbukitan Vulkanik, Bukit Intrusi, Lembah Vulkanik, dan Point Bar. Unsur pembentuk permukaan bumi di kawasan ini terdiri dari empat satuan batuan dari tua ke muda: 1) satuan andesit Jampang (Oligosen Akhir-Miosen Tengah) dan satuan breksi vulkanik Jampang (Oligosen Akhir-Miosen Tengah), 3) satuan dasit Kombongan (Miosen Tengah), satuan andesit Talagawangi (Pliosen), serta 4) satuan endapan aluvial (Resen).

\section{Sumberdaya Produk Wisata}

Kawasan Sungai Cilimbung memiliki daya tarik utama yaitu Air Terjun Jagapati atau pada nama setempat dikenal sebagai Curug Jagapati. Air terjun ini merupakan bagian dari aliran Sungai Cilimbung yang bermata air di Gunung Limbung, dan mengalir ke arah Selatan untuk membentuk Curug Tujuh Neglasari dan bergabung dengan aliran Sungai Cisanggiri yang bermuara di Samudera Indonesia, pantai Selatan Garut. Air terjun membentuk undakan berbentuk zigzag sebanyak 3 tingkatan, terbentuk dari fenomena geologi alami aliran vulkanis purba Sungai Cilimbung. Lebar air terjun 3, memiliki tinggi 10 - 12 meter dengan bagian dasar air terjun membentuk kolam alami berkedalaman 1-2 meter pada debit air normal.

Curug Jagapati secara toponimi terdiri atas 2 suku kata yaitu Jaga: menjaga dan Pati: kematian; menurut penuturan warga setempat memiliki arti menjaga wilayah yang dialirinya dari kematian. Hal ini berkaitan dengan keterkaitan ekologis wilayah setempat dengan aliran sungai untuk kepentingan sumber air bersih, persawahan dan manfaat ekologis lainnya. Sejak tahun 2017, curug ini telah menarik 
kunjungan, namun popularitasnya meningkat pesat setelah publikasi kunjungan Gubernur Jawa Barat di akhir tahun 2020 meluas melalui media sosial.

Tabel 1. Tabel Minat dan Pengaruh Stakeholder

\begin{tabular}{|c|c|c|}
\hline Stakeholder & Minat \& Kepentingan & Pengaruh \\
\hline $\begin{array}{l}\text { Masyarakat Desa } \\
\text { Neglasari }\end{array}$ & $\begin{array}{l}\text { - Perbaikan infrastruktur jalan } \\
\text { - Perluasan kesempatan kerja dan } \\
\text { akses kesejahteraan melalui } \\
\text { pariwisata } \\
\text { - Derajat kepentingan: tinggi }\end{array}$ & $\begin{array}{l}\text { - Kondiseran utama dalam } \\
\text { pengembangan pariwisata } \\
\text { - Derajat pengaruh: tinggi }\end{array}$ \\
\hline $\begin{array}{l}\text { Pemandu wisata } \\
\text { lokal }\end{array}$ & $\begin{array}{l}\text { - Mendapatkan peningkatan } \\
\text { pendapatan dari jasa pemanduan } \\
\text { wisata } \\
\text { - Derajat kepentingan: tinggi }\end{array}$ & $\begin{array}{l}\text { - Kualitas pelayanan wisata } \\
\text { - Derajat pengaruh: tinggi }\end{array}$ \\
\hline $\begin{array}{l}\text { Penyedia Makanan \& } \\
\text { Minuman Lokal }\end{array}$ & $\begin{array}{l}\text { Peningkatan pendapatan dari } \\
\text { kunjungan wisata } \\
\text { - Derajat kepentingan: tinggi }\end{array}$ & $\begin{array}{l}\text { - Penyediaan makanan dan } \\
\text { minuman bagi pengunjung } \\
\text { - Derajat pengaruh: sedang }\end{array}$ \\
\hline Petani lokal & $\begin{array}{l}\text { - Menjadi supplier dalam rantai pasok } \\
\text { pariwisata } \\
\text { - Derajat kepentingan: sedang }\end{array}$ & $\begin{array}{l}\text { Stabilitas pasokan bahan } \\
\text { pangan bagi rantai pasok } \\
\text { setempat } \\
\text { - Derajat pengaruh: rendah }\end{array}$ \\
\hline Penyedia homestay & $\begin{array}{l}\text { - Peningkatan pendapatan dari } \\
\text { kunjungan wisata } \\
\text { - Derajat kepentingan: sedang }\end{array}$ & $\begin{array}{l}\text { - Penyediaan fasilitas } \\
\text { homestay } \\
\text { - Derajat pengaruh: sedang }\end{array}$ \\
\hline $\begin{array}{l}\text { Dinas Kebudayaan \& } \\
\text { Pariwisata Kab Garut }\end{array}$ & $\begin{array}{l}\text { - Pengembangan pariwisata daerah } \\
\text { untuk mendukung IKU instansi } \\
\text { - Penambahan PAD sektor } \\
\text { pariwisata } \\
\text { - Derajat kepentingan: tinggi }\end{array}$ & $\begin{array}{l}\text { - Penentu kebijakan } \\
\text { pengembangan pariwisata } \\
\text { - Derajat pengaruh: tinggi }\end{array}$ \\
\hline $\begin{array}{l}\text { Asosiasi } \\
\text { kepariwisataan di } \\
\text { Kabupaten Garut }\end{array}$ & $\begin{array}{l}\text { - Pengembangan produk dan pasar } \\
\text { wisata } \\
\text { - Derajat kepentingan: sedang }\end{array}$ & $\begin{array}{l}\text { - Penguatan kelembagaan } \\
\text { kepariwisataan } \\
\text { - Derajat pengaruh: sedang }\end{array}$ \\
\hline $\begin{array}{l}\text { Penyedia angkutan } \\
\text { umum }\end{array}$ & $\begin{array}{l}\text { - Peningkatan kualitas jalan dan } \\
\text { angkutan } \\
\text { - Peningkatan pendapatan dari } \\
\text { angkutan antar wilayah } \\
\text { - Derajat kepentingan: sedang }\end{array}$ & $\begin{array}{l}\text { - Penyedia angkutan umum } \\
\text { bagi pengunjung } \\
\text { - Derajat pengaruh: rendah }\end{array}$ \\
\hline $\begin{array}{l}\text { Pokdarwis } \\
\text { Neglasari/Curuh } \\
\text { Jagapati }\end{array}$ & $\begin{array}{l}\text { - Peningkatan kesejahteraan dalam } \\
\text { pengembangan pariwisata } \\
\text { - Derajat kepentingan: tinggi }\end{array}$ & $\begin{array}{l}\text { - Penggerak inisiatif } \\
\text { kepariwisataan di kawasan } \\
\text { pengembangan } \\
\text { - Derajat Pengaruh: tinggi }\end{array}$ \\
\hline
\end{tabular}

Sumber: olahan data penelitian, 2020 
Lanskap Kawasan Sungai Cilimbung yang terdiri atas dataran tinggi, lembah dan perbukitan dengan tutupan vegetasi alam berupa hutan, perkebunan dan persawahan menjadi daya tarik yang saling melengkapi dengan fitur air terjun. Pemandangan ini dapat dinikmati sejak akses utama menuju Desa Neglasari, hingga pada jalur trekking menuju lokasi air terjun yang ditempuh selama 45 menit dari Kampung Padarame sebagai titik distribusi pengunjung. Terdapat potensi aktivitas pengenalan jenis-jenis tumbuhan alami dan budidaya sepanjang jalur trekking Curug Jagapati.

Fasilitas penunjang pariwisata masih dalam tahap rintisan, dimana data lapangan menunjukkan terdapat 1 warung makan yang biasanya digunakan sebagai shelter yang terletak di area depan kawasan. Terdapat 1 unit homestay yang dikelola oleh penduduk, dengan kapasitas 6 orang, namun pada aspek sanitasi dan kamar mandi sangat perlu ditingkatkan. Gapura penanda telah tersedia, namun tidak dilengkapi dengan ruang pengelola sehingga keperluan pengunjung untuk pemandu wisata lokal memanfaatkan bangunan semi permanen atau memanfaatkan rumah penduduk. Penanda masuk di jalur utama Garut-Pameungpeuk sudah tersedia, desain tipografi-nya yang kecil, seringkali terlewati oleh pengunjung.

Kawasan Sungai Cilimbung terletak sekitar $60 \mathrm{Km}$ dari pusat kota Garut, atau setara 2,5 jam menggunakan kendaraan pribadi melalui jalur Garut-Pameungpeuk. Akses jalan utama dari jalur utama kendaraan Garut - Pameungpeuk berkategori jalan kelas 2, dan secara umum kondisinya perlu ditingkatkan. Pada area dalam kawasan, jalur trekking berupa jalan setapak dengan tutupan batuan dan mayoritas tanah, sehingga saat musim hujan tiba, menyulitkan untuk pengunjung dengan tipologi mass-tourist. Masyarakat dan pemerintah desa telah berupaya membuat undakan pada tebing terjal di area inti, kemiringan jalur yang mencapai 60 derajat cukup melelahkan bagi pengunjung.

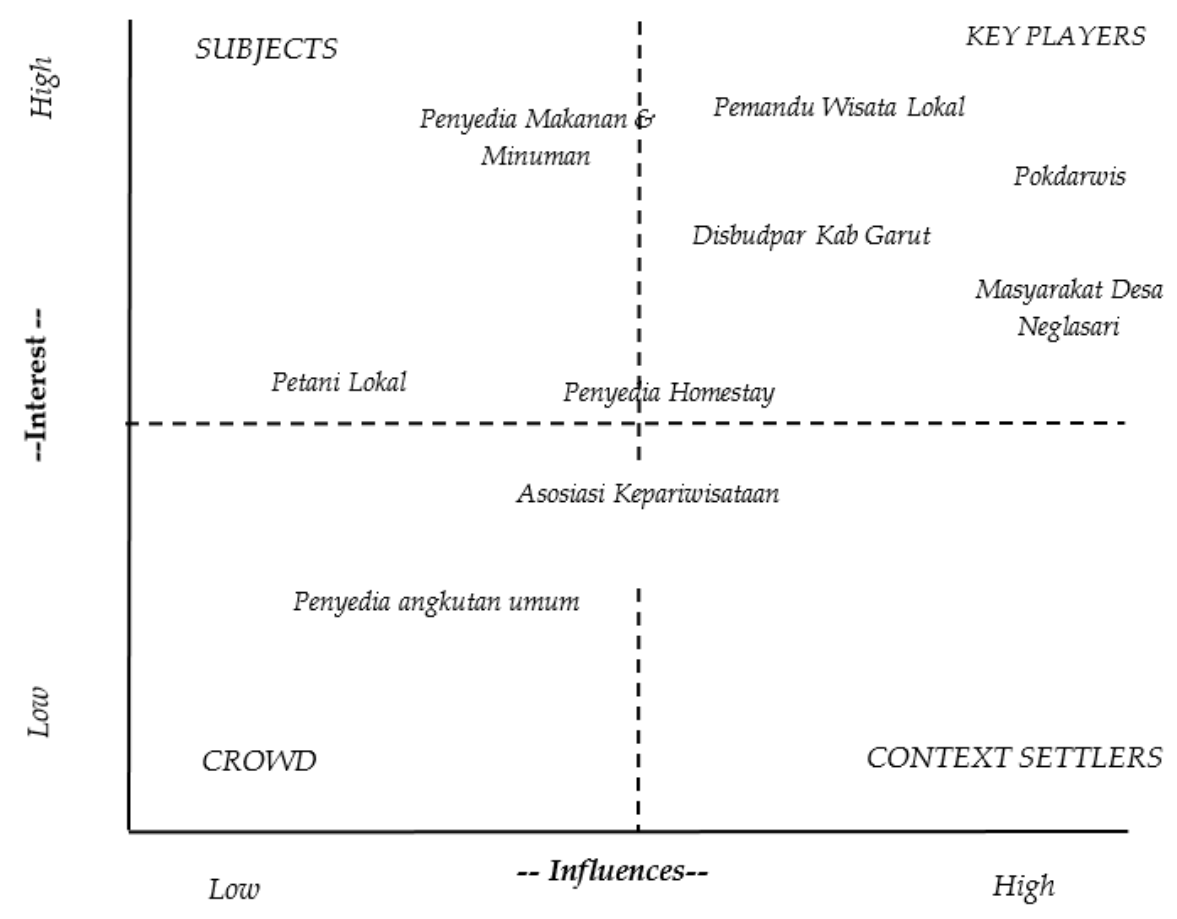

Gambar 3. Matrix Stakeholder Analysis

Sumber: modifikasi (Reed et al., 2009) dan data wawancara, 2021 


\section{Sumberdaya Sosial}

Pada aspek sumberdaya sosial, Desa Neglasari memiliki penduduk 2.612 jiwa, dengan tingkat pendidikan rata-rata SMPSMA, mata pencaharian mayoritas adalah petani atau pekerjaan yang berhubungan dengan pertanian. Jumlah penduduk pada angkatan kerja mendominasi profil demografi wilayah ini, sehingga untuk penyediaan tenaga kerja pendukung pariwisata memiliki potensi yang cukup besar.

Keterlibatan masyarakat pada kegiatan pariwisata di Kawasan Sungai Cilimbung, khususnya terkait Curug Jagapati berupa penyediaan tenaga pemandu wisata lokal, penyediaan makanan dan minuman, penyediaan homestay serta penyediaan angkutan ojek. Telah terbentuk Kelompok Sadar Wisata (Pokdarwis) Curug Jagapati yang dibina oleh Pemerintah Desa Neglasari bersama Dinas Kebudayaan dan Pariwisata Kabupaten Garut. Program kerja Pokdarwis disusun untuk mewujudkan pengembangan kawasan wisata Curug Jagapati menjadi daerah rintisan pengembangan kepariwisataan berbasis alam.

\section{Strategi Pengembangan}

Kawasan Sungai Cilimbung dapat dikembangkan sebagai kawasan wisata alam dengan tema experiential tourism yaitu sebuah kawasan wisata yang memberikan keleluasaan bagi pengunjung untuk menjelajahi kawasan dengan pendekatan petualangan keluarga, agro dan edukasi. Prinsip tersebut sejalan dengan beberapa kajian pengembangan kawasan wisata di destinasi yang berbeda (Meacci \& Liberatore, 2018; Serdane et al., 2020) Platform pengembangan ini diwujudkan melalui pengemasan aktivitas sebagai berikut: 1) trekking: menjelajahi aliran sungai Cilimbung dengan Curug Jagapati sebagai main attraction, dapat diperluas dengan menjelajahi jalur tematik geologis, botani dan ekosistem sungai; 2) agro- adventures: pengemasan aktivitas wisata menjelajahi hutan lindung dan kawasan perkebunan untuk mengenal jenis tumbuhan, bird watching dan menikmati hasil olahan perkebunan setempat dengan aktivitas kuliner sebagai main attraction; 3 ) wisata otomotif dengan mengembangkan jalur off-road sepeda motor dengan jalur terpisah dari aktivitas non-otomotif.

Untuk mendukung pengemasan tersebut, pola pengembangan kawasan dibagi setidaknya menjadi tiga, yaitu: 1) zona inti: meliputi Air Terjun Jagapati dan aliran Sungai Cilimbung sebagai atraksi utama dan pengikat aktivitas wisata di kawasan inti; 2) zona penyangga: meliputi kawasan penyangga dari aliran sungai Cilimbung yang digunakan secara terbatas dengan mengutamakan kelesetarian fungsi ekologis dan penyebaran aktivitas wisata untuk mengurangi beban pada zona inti; 3) zona pengembangan: wilayah yang dicadangkan sebagai zona pengembangan aktivitas dan fasilitas di masa mendatang; 4) zona pendukung: wilayah yang digunakan sebagai titik distribusi pengunjung, fasilitas komersial dan area pusat sirkulasi kunjungan yang terletak di bagian depan/area pintu masuk kawasan. Sirkulasi kunjungan yang direkomendasikan yaitu secara loop-line dan back-trekking dimana arus keluar dan masuk pengunjung menggunakan satu pintu akses yang saat ini telah tersedia, pada bagian dalam diatur sirkulasi jalur kunjungan yang berbeda antara jalur menuju zona inti dan keluar dari zona inti. Hal ini dilakukan untuk menekan dampak kepadatan aktivitas kunjungan di dalam kawasan, menyebarkan aktvitas wisata dan mengoptimalkan pengalaman berkunjung (Albrecht, 2017; Budisetyorini et al., 2021; Morrison, 2013)

Pada aspek pengelolaan, direkomendasikan strategi pengelolaan dengan memperkuat fungsi Kelompok Sadar Wisata Desa Neglasari yang saat ini telah ada sesuai prinsip community based tourism (Khalid et al., 2019; Robinson et al., 2020; Sheldon \& Fesenmaier, 2017). 
Penguatan kelembagaan dapat ditempuh melalui strategi sebagai berikut: 1) pembentukan struktur organisasi, dilengkapi dengan pengukuhan pada aspek yuridis formal; 2) pelatihan peningkatan kapasitas SDM secara bertahap, dimulai dengan pelatihan pelayanan pengunjung, pelatihan $\mathrm{K} 3$ dan bisnis; 4) memperkuat inklusi rantai pasok kepariwisataan dengan memprioritaskan produk dari dalam kawasan Desa Neglasari Kecamatan Cisompet Kabupaten Garut.

\section{KESIMPULAN}

Kawasan Sungai Cilimbung dapat dikembangkan sebagai kawasan wisata alam dengan tema experiential tourism yaitu sebuah kawasan wisata yang memberikan keleluasaan bagi pengunjung untuk menjelajahi kawasan dengan pendekatan petualangan keluarga, agro dan edukasi. Pada aspek pengelolaan, direkomendasikan strategi pengelolaan dengan memperkuat fungsi Kelompok Sadar Wisata Desa Neglasari yang saat ini telah ada. Model pengembangan aktivitas wisata berbasis sungai di Sungai Cilimbung Desa Neglasari diarahkan kepada model pengembangan pariwisata berbasis masyarakat yang berkelanjutan (Khalid et al., 2019).

Untuk mewujudkan hal tersebut, pendekatan pengembangan tidak bertumpu pada inisiatif pemerintah, namun dapat mengelaborasi minat dan kepentingan setiap stakeholder. Penelitian ini telah memberikan suatu informasi mengenai sumberdaya pariwisata di Kawasan Sungai Cilimbung serta berkontribusi dalam pengayaan ilmu terapan kepariwisataan sebagai bahan pertimbangan pengembangan pariwisata di objek penelitian dan wilayah lain yang relevan.

Keterbatasan penelitian ini yaitu belum mampu mengungkap aspek teknis perencanaan fisik, pelayanan dan operasional. Hal ini memberikan peluang bagi penelitian lanjutan yang akan memberikan kontribusi penting bagi obyek penelitian. Pada aspek pemberdayaan masyarakat, penelitian ini memberikan peluang untuk penelitian terapan berupa panduan aktivasi unsur sosial dalam pengembangan kawasan Cilimbung. Pada gilirannya, seluruh bentuk penelitian yang berfokus pada pengembangan kawasan ini diyakini dapat memberikan kontribusi pada kajian kepariwisataan dan kesejahteraan masyarakat Desa Neglasari Kecamatan Cisompet Kabupaten Garut.

\section{PENGAKUAN}

Penelitian ini didanai oleh program penelitian dosen Unit Penelitian dan Pengabdian Kepada Masyarakat Sekolah Tinggi Pariwisata Bandung yang bekerjasama dengan Dinas Kebudayaan dan Pariwisata Jawa Barat. Ucapan terimakasih kami ucapkan kepada seluruh pihak yang terlibat dalam penelitian ini. 


\section{DAFTAR PUSTAKA}

Ajake, A. O., \& Amalu, T. E. (2012). The relevance of tourism on the economic development of Cross River State, Nigeria. Journal of Geography and Regional Planning, 5(1), 14-20. https:// doi.org/10.5897/jgrp11.122

Albrecht, J. N. (2017). Visitor Management in Tourism Destinations. In J. N. Albrecht (Ed.), Tourism Management Research. CABI.

Badan Perencanaan Pembangunan Daerah Jawa Barat. (2017). Rencana besar pengembangan destinasi wisata kelas dunia Provinsi Jawa Barat. In Badan Perencanaan Pembangunan Daerah Provinsi Jawa Barat.

Beardsley, M., Graaf, E. van der, Grandpré, F. de, Hohn, A., Ilves, R., Kadijk, H., Komppula, R., Konu, H., Maris, D. K., LeBlanc, M., Matteucci, X., Mitas, O., Nawijn, J., NaudéPotgieter, R.-A., Peperkamp, E., Pesonen, J., Puczkó, L., Royer, C., Smith, M. K., ... Zátori, A. (2018). Managing Quality of Life in Tourism and Hospitality (M. Uysal, M. J. Sirgy, \& S. Kruger (eds.)). CABI Publishing.

Brouder, P., Teoh, S., Salazar, N. B., Mostafanezhad, M., Pung, J. M., Lapointe, D., Higgins Desbiolles, F., Haywood, M., Hall, C. M., \& Clausen, H. B. (2020). Reflections and discussions: tourism matters in the new normal post COVID-19. In Tourism Geographies (Vol. 22, Issue 3, pp. 735-746). https:// doi.org/10.1080/14616688.2020.1770325

Budisetyorini, B., Adisudharma, D., Fitriani, M., Prawira, A., Salam, A., Wulandari, W., \& Susanto, E. (2021). Pengembangan Pariwisata Bertema Eco-Forest dan Sungai di Bumi Perkemahan Tangsi Jaya. 5, 75-88. https:// doi.org/10.34013/jk.v5i1.220

Cooper, C. (2016). Essentials of Tourism (2nd Editio). Pearson Education Limited. https:/ / books.google.com/books?hl=en\&lr=\&id=ASEAEAAAQBAJ\&oi=fnd\&pg=PP1 \&dq=application+of+technology+in+tourism\&ots=-Jgp3SrWz6\&sig=kb6OLJ4h1pI83LzzWiaq38jkgI

Ioannides, D., \& Gyimóthy, S. (2020). Tourism Geographies An International Journal of Tourism Space, Place and Environment The COVID-19 crisis as an opportunity for escaping the unsustainable global tourism path. https:// doi.org/10.1080/14616688.2020.1763445

Khalid, S., Ahmad, M. S., Ramayah, T., Hwang, J., \& Kim, I. (2019). Community Empowerment and Sustainable Tourism Development: The Mediating Role of Community Support for Tourism. In Sustainability (Vol. 11, Issue 22). https:/ / doi.org/10.3390/su11226248

Koh, E. (2020). The end of over-tourism? Opportunities in a post-Covid-19 world. International Journal of Tourism Cities, 6(4), 1015-1023. https:/ / doi.org/10.1108/ IJTC-04-2020-0080

Kozak, M., \& Kozak, N. (2018). Tourist Behavior: An Experiential Perspective. Springer International Publishing AG. http://www.springer.com/series/15444

Mafruhah, I., Supriyono, S., Mulyani, N. S., \& Istiqomah, N. (2020). Causality between tourism industry development and the ecological sustainability in marine environment: A convergence and divergence among stakeholder with mactor analysis. International Journal of Energy Economics and Policy, 10(4), 85-92. https:/ / doi.org/10.32479/ijeep.7989

Meacci, L., \& Liberatore, G. (2018). A senses-based model for experiential tourism. Tourism $\mathcal{E}$ Management Studies, 14(4), 7-14. https://doi.org/10.18089/tms.2018.14401 
Morrison, A. M. (2013). Marketing and managing tourism destinations. In Marketing and Managing Tourism Destinations. https://doi.org/10.4324/9780203081976

Peraturan Daerah Kabupaten Garut Nomor 1 Tahun 2019 Tentang Rencana Pembangunan Jangka Menengah Daerah Tahun 2019-2024 Kabupaten Garut, (2019).

Peraturan Daerah No 2 Tahun 2019 Tentang Rencana Induk Pembangunan Kepariwisataan Daerah Tahun 2019-2025, 1 (2019).

Pemerintah Provinsi Jawa Barat. (2015). Peraturan Daerah Provinsi Jawa Barat No 15 Tahun 2015 Tentang Rencana Induk Pembangunan Kepariwisataan Provinsi Jawa Barat Tahun 2015-2025.

Peters, K., Peters, J., \& Peters, N. (2020). Visit people Tourism Recovery after disaster Literature Review. April.

Prawira, N. G., Johari, A., Prawira, M. F. A., \& Susanto, E. (2020). Sumber Daya Alam dan Kearifan Lokal sebagai Rasional dalam Workshop Visual branding Kawasan Wisata Pantai Plentong Kabupaten Indramayu Jawa Barat. JATI EMAS (Jurnal Aplikasi Teknik Dan Pengabdian Masyarakat), 4(2), 49. https://doi.org/10.36339/je.v4i2.307

Putro, H. P. N., Jumriani, Abbas, E. W., \& Aprilla, W. (2021). Impact of Tourism for Economic Activities of Riverbank Communities in the Jingah River District, Banjarmasin City. Proceedings of the 2nd International Conference on Social Sciences Education (ICSSE 2020), 525(Icsse 2020), 372-375. https:// doi.org/10.2991/assehr.k.210222.061

Reed, M. S., Graves, A., Dandy, N., Posthumus, H., Hubacek, K., Morris, J., Prell, C., Quinn, C. H., \& Stringer, L. C. (2009). Who's in and why? A typology of stakeholder analysis methods for natural resource management. Journal of Environmental Management, 90(5), 1933-1949. https:/ / doi.org/10.1016/j.jenvman.2009.01.001

Robinson, P., Lück, M., \& Smith, S. (2020). An introduction to tourism. In Tourism. https:// doi.org/10.1079/9781789241488.0003

Serdane, Z., Maccarrone-Eaglen, A., \& Sharifi, S. (2020). Conceptualising slow tourism: a perspective from Latvia. Tourism Recreation Research, 45(3), 337-350. https:// doi.org/10.1080/02508281.2020.1726614

Sheldon, P. J., \& Fesenmaier, D. R. (2017). Social Entrepreneurship and Tourism: Philosophy and Practice. Springer International Publishing AG. https://doi.org/10.1007/978-3-31946518-0

Smith, W. L. (2006). Experiential tourism standards: The perceptions of rural tourism providers. International Journal of Services and Standards, 2(3), 273-285. https:// doi.org/10.1504/IJSS.2006.009758

Susanto, E., Novianti, S., Rafdinal, W., Prawira, M. F. A., \& Septyandi, C. B. (2020). Visiting Tourism Destination: Is It Influenced by Smart Tourism Technology? Journal of Indonesian Tourism and Development Studies, 8(3), 145-155. https:// doi.org/10.21776/ub.jitode.2020.008.03.04

UNWTO. (2020). International Tourism Highlights 2020 Edition. In UNWTO Reports.

UNWTO. (2021). TOURISM IN THE 2030 AGENDA. TOURISM IN THE 2030 AGENDA. https:// www.unwto.org/tourism-in-2030-agenda 
Veal, A. J. (2018). Research methods for leisure and tourism. In Annals of Tourism Research (5th ed.). Pearson Education Limited. 